\title{
Campylospora leptosoma sp. nov. and characteristics of Campylospora spp., based on morphology and on ITS sequences.
}

\section{Marvanová L and Laichmanová M}

\begin{abstract}
Masaryk University, Faculty of Science, Institute of Experimental Biology, Czech Collection of Microorganisms,
\end{abstract} University Campus Bohunice, Kamenice 753/5, 62500 Brno, Czech Republic. ludmila@sci.muni.cz.

Marvanová L, Laichmanová M 2014 - Campylospora leptosoma sp. nov. and characteristics of Campylospora spp., based on morphology and on ITS sequences. Mycosphere 5(2), 245-261, Doi 10.5943/mycosphere/5/2/1

\begin{abstract}
Campylospora leptosoma is described as new species. C. filicladia and C. parvula are lectotypified, epitypes of $C$. filicladia and $C$. parvula are established. ITS-based phylogenetic analysis of 18 isolates of four species of Campylospora confirms monophyly of the genus. Delimitation of C. chaetocladia, C. filicladia and C. parvula based on morphology is supported by phylogenetic analysis. C. leptosoma, although morphologically homogeneous, falls into two groups: one forms a well supported sister clade of $C$. parvula, the other an unsupported sister clade of $C$. chaetocladia.
\end{abstract}

Key words - aquatic hyphomycetes - Campylospora chaetocladia - C. filicladia - C. parvula epitypes - lectotypes

\section{Introduction}

The asexual aquatic hyphomycete genus Campylospora was introduced with a single species C. chaetocladia Ranzoni from California, USA (Ranzoni 1953). After 20 years, a second species, C. parvula Kuzuha was described from Japan (Kuzuha 1973). The last species, C. filicladia Nawawi, was published one year later from Malaysia (Nawawi 1974). The name Campylospora tetracladia was informally published by Ingold (1967) for a Campylospora whose conidia were collected in the UK.

Conidia of Campylospora spp. are reported with variable frequency from ecological or biodiversity-aimed studies based on detached conidia collected in stream water or stream foam. Although relatively well identifiable at the genus level, identification of species based on conidial morphology may be problematic, because the morphological differences especially among the small-spored species are rather subtle; misidentifications appear in the literature (see below). Alternatively, it is possible to employ molecular methods based on comparison of nucleotide sequences of the ITS1, 5.8S and ITS2 rDNA gene region (barcoding, Rossmann 2007). This approach promises to assess the taxonomic distance among species more accurately and will contribute to the slowly increasing pool of barcodes for aquatic hyphomycetes.

During the last few years we had the opportunity to isolate Campylospora species from several localities; one species appeared to be undescribed. Our isolates of the latter from Malaysia fit well into the concept of Campylospora based on conidiogenesis and conidial morphology. 
Holotypes of Campylospora species are poorly represented in herbaria and ex-type cultures are absent in registered culture collections, therefore lectotypification of $C$. filicladia and $C$. parvula has been effected here. In order to base phylogenetic characterization on reliably identified strains, we also propose epitypes and one representative strain. The goal of this study is (1) to describe a new species of Campylospora, (2) to add information on the known species based on freshly isolated cultures and (3) to provide ITS-based phylogenetic analysis of 18 isolates belonging to four species of Campylospora.

\section{Material and methods}

\section{Fungal isolates}

The CCM cultures are monoconidial isolates obtained during 2008 - 2010 from decaying frondose tree leaves and other plant debris collected in streams. In laboratory the substrates were thoroughly rinsed under tap water and incubated in standing distilled water for several days at $15^{\circ} \mathrm{C}$ in diffuse light. Conidia released into water were transferred with a flamed loop onto a thin layer of 0.5\% malt extract agar (MEA, HiMedia) supplemented with a mixture of penicillin and streptomycin (Sigma) and incubated at $15^{\circ} \mathrm{C}$. After $24-48$ hours, germinating conidia were located under low power of compound microscope, cut out with a piece of agar and transferred on the same medium in Petri dishes. Sporulation was achieved by submerging a small slice of the colony in standing distilled water at ambient temperature $\left(22-25^{\circ} \mathrm{C}\right)$. For colony description of the new species, the isolates were cultured on 2\% MEA (HiMedia), one also on DRBC (HiMedia) at laboratory temperature $\left(22-24^{\circ} \mathrm{C}\right)$ Drawings were prepared from semi-permanent preparations in lacto-fuchsine, with phase contrast objective 100 under immersion oil, with the aid of drawing tube of Olympus BX 50 microscope. Microphotographs were done with a digital camera Artcam 500 MI. Colony colour was estimated according to Rayner (1970). In order to facilitate comparison with conidia of $C$. filicladia, which can be confused with small ones of our new species, we measured the conidial body like illustrated in Nawawi (1974) (see our Fig. 26): in the triangular part the first given value is the distance from base to the lowest point between the arms, the second is the distance between apices of the arms. The heel-like pedicel is measured from the conidial base to the foot of the lateral arm. The other conidial elements are measured traditionally from base to apex and across the widest part.

\section{DNA extractions, PCR, DNA sequencing and phylogenetic analyses}

Genomic DNA was isolated from mycelia grown on $2 \%$ MEA (HiMedia) plates at laboratory temperature. Fourteen days old mycelium was placed in a mortar with liquid nitrogen and powdered. DNA was extracted by using the DNeasy Plant Mini Kit (Qiagen, Germany). The ITS rDNA region (ITS1-5.8S-ITS2) was amplified with the primers ITS 5 and ITS4 or ITS3 and ITS4 (White et al. 1990) for Campylospora filicladia. The ITS regions of Campylospora filicladia failed to amplify with the primer pairs ITS5, ITS4; ITS1, ITS4; ITS5, ITS2; ITS1, ITS2; SR6R (Vilgalys 2000, [http://www.biology.duke.edu/fungi/mycolab/primers.htm]), LR 1 (Vilgalys \& Hester 1990); ITS1 F (Gardes \& Bruns 1993) and ITS4. The PCR mixture (25 $\mu \mathrm{l})$ contained $100 \mathrm{ng}$ genomic DNA, 20 pmol of each primer, $0.2 \mathrm{mM}$ dNTP PCR Mix (Serva, Germany), $2.5 \mu 1$ of 10x ThermoPol Reaction Buffer $\left(100 \mathrm{mM} \mathrm{KCl}, 100 \mathrm{mM}\left(\mathrm{NH}_{4}\right)_{2} \mathrm{SO}_{4}, 200 \mathrm{mM}\right.$ Tris-HCL, $20 \mathrm{mM}$ $\mathrm{MgSO}_{4}, 0.1 \%$ Triton $\mathrm{X}-100, \mathrm{pH} 8.8$ ) and $1.5 \mathrm{U}$ of Taq DNA polymerase (BioLabs, New England). PCR reactions were performed in a $\mathrm{T}$-professional thermocycler (Biometra) with an initial denaturation step $\left(94^{\circ} \mathrm{C}, 3 \mathrm{~min}\right)$, followed by 30 cycles of denaturation $\left(94^{\circ} \mathrm{C}, 30 \mathrm{~s}\right)$, primer annealing $\left(55^{\circ} \mathrm{C}, 30 \mathrm{~s}\right)$, extension $\left(72^{\circ} \mathrm{C}, 1 \mathrm{~min}\right)$ and final extension $\left(72^{\circ} \mathrm{C}, 5 \mathrm{~min}\right)$. The PCR products were checked on $1 \%$ agarose gel (Bio-Rad Laboratories, USA) at $100 \mathrm{~V}$, then purified by High Pure PCR Product Purification Kit (Roche, Germany) and sequenced with ITS5 or ITS3 primers by Eurofins MWG Operon Sequencing Department (Germany). The sequences of 18 Campylospora strains were submitted to GenBank and their accession numbers are listed in Table 
1. Sequences of the ITS rDNA region were aligned by the ClustalW program (Thompson et. al.1994) and manually checked and adjusted. The phylogenetic tree for ITS rDNA was constructed using neighbor-joining (Saitou \& Nei 1987) and maximum parsimony (Swofford et al. 1996; Saitou 1996) with the MEGA 4 program (Tamura et al. 2007). Sequence divergence was analysed using the Jukes-Cantor distance model (Jukes \& Cantor 1969). Branch support was tested by 1000 replications on bootstrapped data sets (Felsenstein 1985). The ITS sequence of Calonectria hurae downloaded from GenBank was used as the outgroup.

Table 1 Provenance of cultures and GenBank accession numbers

\begin{tabular}{|c|c|c|c|}
\hline Species & Strain No. & Country of origin & $\begin{array}{l}\text { GenBank } \\
\text { No. }\end{array}$ \\
\hline Campylospora chaetocladia & CCM F-17708 & Greece (Corfu) & JN190876 \\
\hline Campylospora chaetocladia & CCM F-10610 & Malaysia(Borneo) & JN190877 \\
\hline Campylospora chaetocladia & CCM F-10710 & Malaysia(Borneo) & JN190878 \\
\hline Campylospora chaetocladia & CCM F-10810 & Malaysia(Borneo) & JN190879 \\
\hline Campylospora filicladia & CCM F-10010 & Malaysia(Borneo) & JN190880 \\
\hline Campylospora filicladia & CCM F-10110 & Malaysia(Borneo) & JN190881 \\
\hline Campylospora filicladia & CCM F-10210 & Malaysia(Borneo) & JN190882 \\
\hline Campylospora filicladia & CCM F-10310 & Malaysia(Borneo) & JN190883 \\
\hline Campylospora parvula & CCM 8044 & $\begin{array}{l}\text { Alnus root endophyte } \\
\text { United Kingdom (= P. Fisher 223) }\end{array}$ & JN190870 \\
\hline Campylospora parvula & CCM F-13708 & Malaysia (mainland) & JN190868 \\
\hline Campylospora parvula & CCM F-14308 & Malaysia (mainland) & JN190869 \\
\hline Campylospora parvula & CCM F-14908 & Malaysia (mainland) & JN190867 \\
\hline Campylospora parvula & CCM F-15008 & Malaysia (mainland) & JN190866 \\
\hline Campylospora leptosoma* & BCRC 33290 & Rotten leaf, Taiwan & JN190875 \\
\hline Campylospora leptosoma & CCM F-15308 & Malaysia (mainland) & JN190871 \\
\hline Campylospora leptosoma & CCM F-15408 & Malaysia (mainland) & JN190873 \\
\hline Campylospora leptosoma & CCM F-16008 & Malaysia (mainland) & JN190872 \\
\hline Campylospora leptosoma & CCM F-10510 & Malaysia (Borneo) & JN190874 \\
\hline
\end{tabular}

*received as $C$. filicladia from BCRC (Bioresources Collection and Research Center, Taiwan)

\section{Results}

\section{Phylogeny}

The ITS1-5.8S-ITS2 region of C. leptosoma, C. parvula and C. chaetocladia consisted of $468-535 \mathrm{bp}$. The ITS1 region contained $144-178 \mathrm{bp}$, the $5.8 \mathrm{~S}$ region consisted of $158 \mathrm{bp}$ in each of the examined strains of $C$. leptosoma, $C$. parvula and $C$. chaetocladia. In the isolates of $C$. filicladia we failed to obtain sequences of the ITS 1 region. The partial sequences of the 5.8S-ITS2 region were $236 \mathrm{bp}$ long, out of which 65 bp represent the $5.8 \mathrm{~S}$ region.

All four species of Campylospora differ in the ITS2 sequences with lengths of $163-167 \mathrm{bp}$ in five strains of $C$. parvula, $176-199 \mathrm{bp}$ in five strains of $C$. leptosoma, $187 \mathrm{bp}$ in four strains of C. chaetocladia and $171 \mathrm{bp}$ in four strains of $C$. filicladia. The ITS2 sequences varied in length among the species by $5-36 \mathrm{bp}$. The average overall evolutionary divergence for all ITS1-5.8SITS2 sequences was, according to the Jukes-Cantor pairwise distance model, 13\%. Pairwise distance calculation showed a small percentage of nucleotide differences $(0-1.84 \%)$ in the case of intraspecific variation in $C$. chaetocladia, $C$. filicladia and $C$. parvula. While the evolutionary divergences among Campylospora species were $13-18.3 \%$, these were much smaller within isolates of individual species. For four isolates of $C$. filicladia (originating from the same locality), these were zero; the isolates of $C$. chaetocladia (one from Europe, three from Borneo) differed by $0.26 \%$; among the isolates of $C$. parvula (four from decaying leaves in stream in the mainland of Malaysia and one endophytic isolate from riparian roots of Alnus glutinosa in UK) the distance value was $1.84 \%$. The sequences of $C$. leptosoma isolates exhibited rather high evolutionary divergences $(10 \%)$ among five isolates (four of them originated from streams in the mainland of 
Table 2 Evolutionary divergence (\%) among Campylospora species based on ITS sequences. The number of base substitutions per site from averaging overall sequence pairs between the species is shown. Analyses used the Jukes-Cantor method.

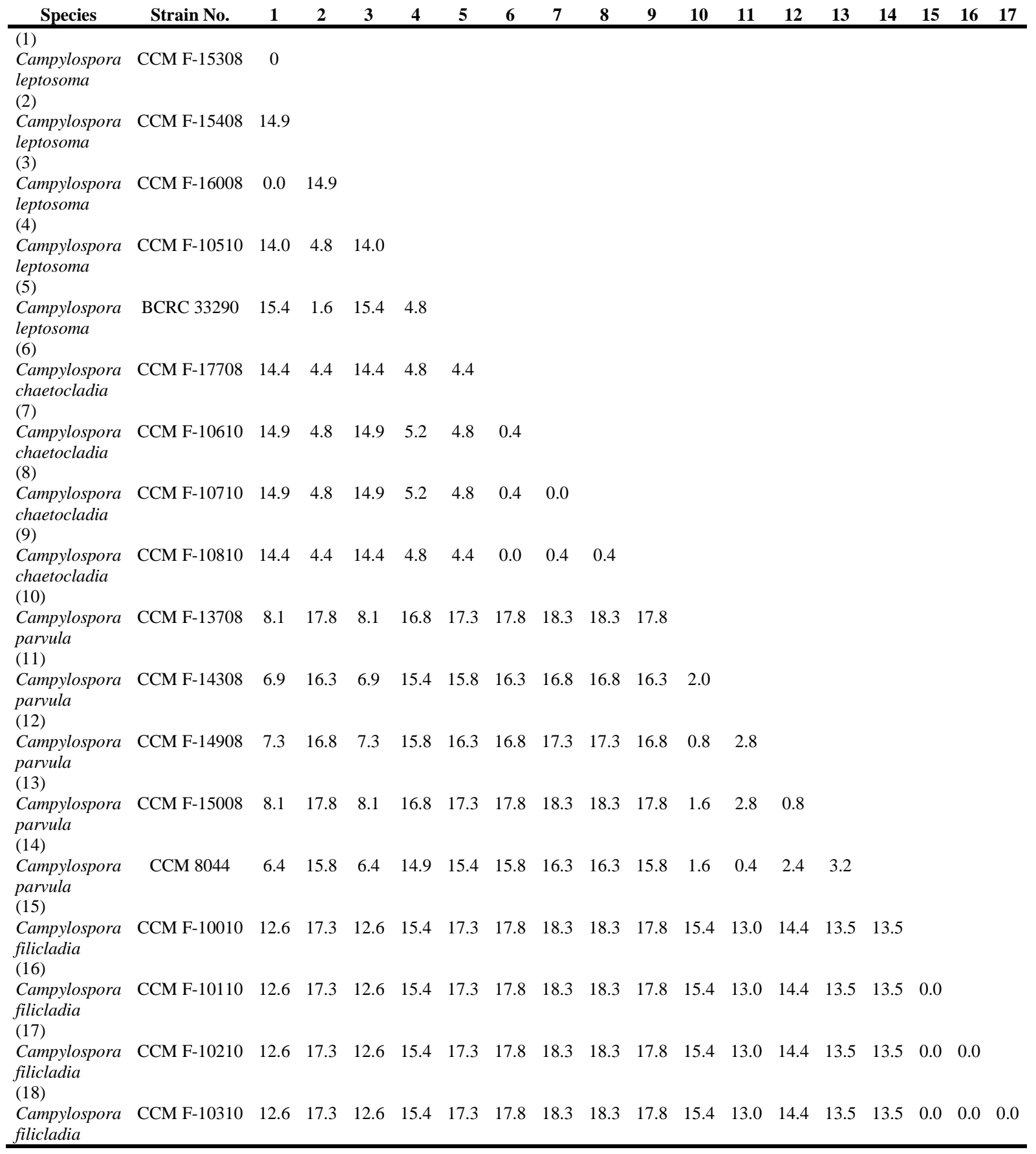

Malaysia and in Borneo and one from Taiwan), while the differences between C. leptosoma and other Campylospora species varied from $4.4-17.8 \%$. The evolutionary differences among Campylospora species based on ITS1-5.8S-ITS2 sequences are shown in Table 2.

As the closest ITS sequences obtained through the BLAST search we found some species of Calonectria, Volutella and Colletotrichum. The evolutionary divergences among them and Campylospora species were about $18 \%$ (not shown). Therefore we conclude that the hitherto known Campylospora spp. have affinities to Sordariomycetes. 


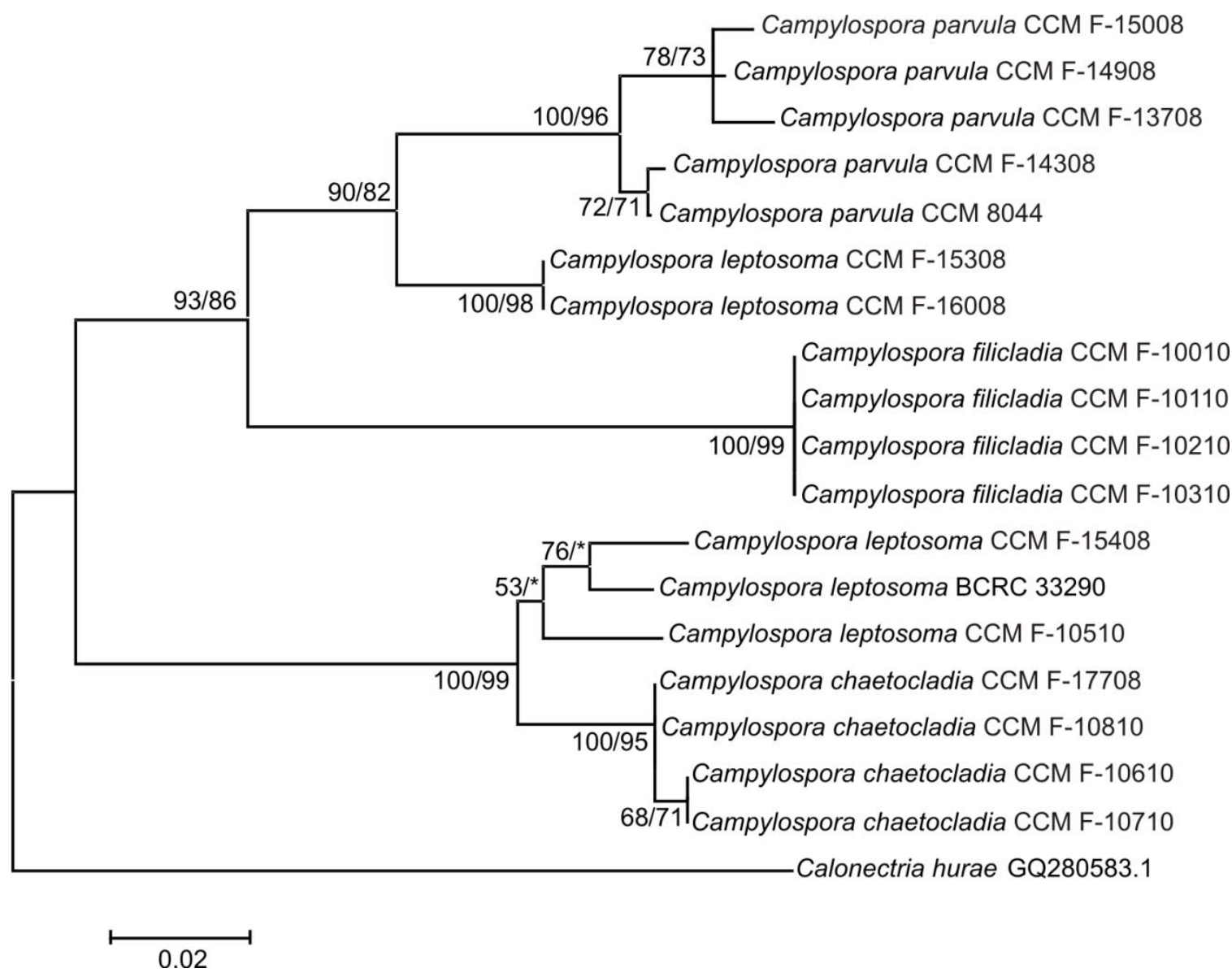

Fig. 1 - Phylogenetic tree reconstructed by neighbor joining method based on fragment of ITS sequences using Jukes-Cantor correction. Calonectria hurae is used as the outgroup taxon. Scale bar indicates one base change per 100 nucleotide positions. Numbers refer to bootstrap support (NJ/MP). Bootstrap values higher than $50 \%$ are indicated at the branch points.

*lower bootstrap support than $50 \%$

Almost the same topologies were obtained in both methods of tree construction. The absence of ITS1 sequences in C. filicladia strains did not influence essentially the tree topology (not shown). The bootstrap consensus tree resulting from NJ analysis based on ITS sequences grouped the isolates of Campylospora in separate clades of $C$. parvula, $C$. filicladia and $C$. chaetocladia with high bootstrap support in the NJ and MP analyses (Figs. 1, 2). In contrast, the isolates of C. leptosoma formed two clusters. One was formed by two strains (CCM F-15308 and CCM F-16008) from Malaysia (mainland) with bootstrap support (100\% and 98\% in NJ and MP, respectively) and with $0 \%$ divergences. These two strains are phylogenetically close to $C$. parvula what is confirmed by the lower divergences $(7.4 \%)$ between the above mentioned isolates of $C$. leptosoma and C. parvula. The second cluster was formed by CCM F-15408 (Malaysia mainland), CCM F-10510 (Borneo) and BCRC 33290 (Taiwan) without bootstrap support (53\% in NJ) and with intraspecific variation $3.7 \%$. This cluster is phylogenetically close to C. chaetocladia. The evolutionary differences between these three isolates of $C$. leptosoma and $C$. chaetocladia were $4.8 \%$.

The distance values between the two clades of $C$. leptosoma are similar to those separating different Campylospora species (14.7\%).

\section{Taxonomy}

Campylospora is characterized with colonies in isabelline tones, hyaline to pale brown hyphae including variously shaped inflated cells, integrated conidiogenous cells typically proliferating sympodially. Characteristic for all species is a strongly recurved conidial primordium 


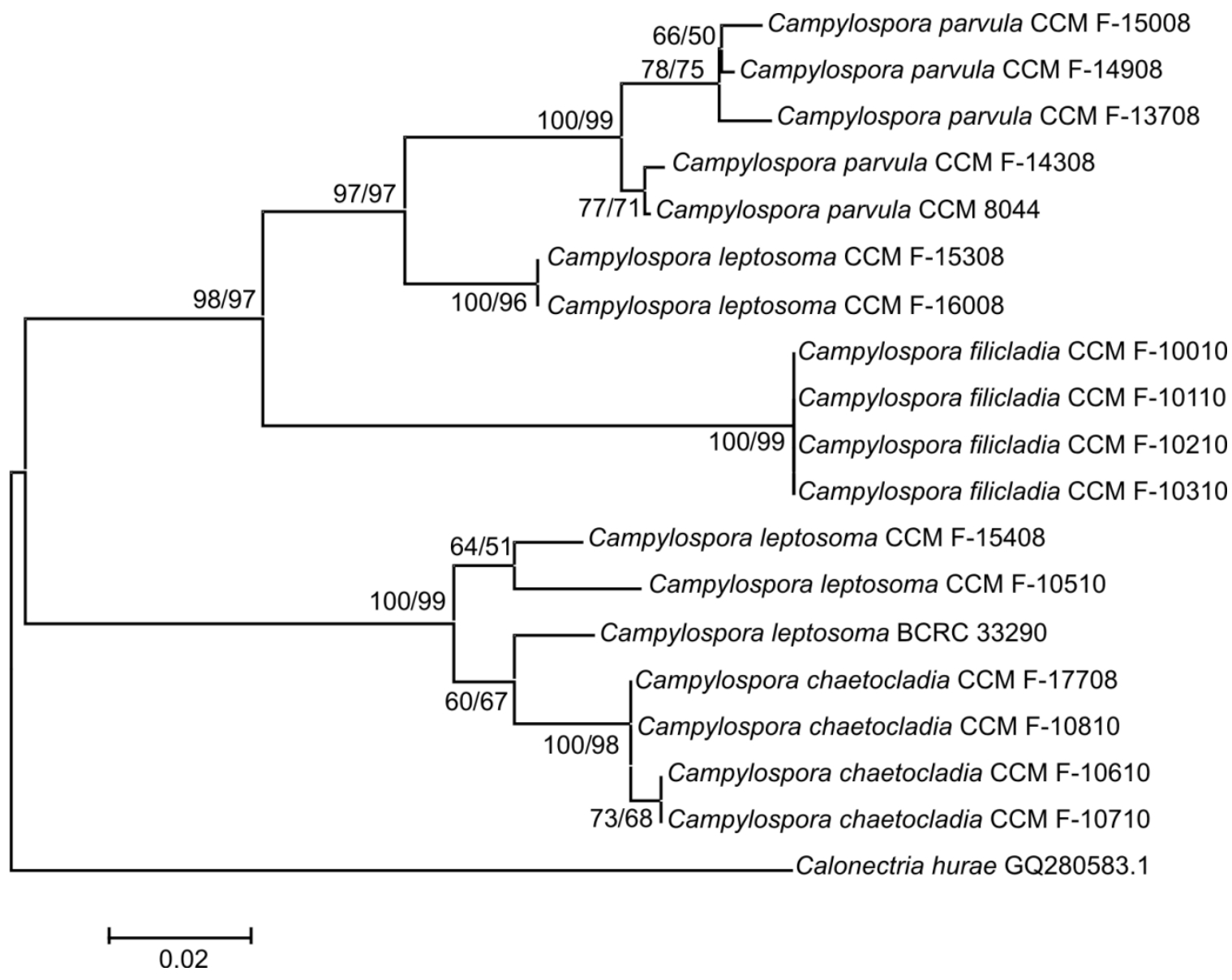

Fig. 2 - Phylogenetic tree reconstructed by neighbor joining method based on fragment of ITS2 sequences using Jukes-Cantor correction. Calonectria hurae was used as outgroup. Numbers refer to bootstrap support (NJ/MP). Scale bar indicates one base change per 100 nucleotide positions. Bootstrap values higher than $50 \%$ are indicated at the branch points.

during the early stage of development, resembling a "crozier" stage of ascogenous hyphae during the early fruit body differentiation (Ranzoni 1953). The primordium starts as a clavate outgrowth on the conidiophore apex, soon elongating and becoming strongly recurved. A septum is laid down at the point of bending. Two new growth points appear at the proximal side of the septum, giving rise to the first conidial part; on the distal side of the septum the second conidial part is formed. At this stage cellular appendages start to grow simultaneously from the conidial end cells. Mature conidia are bipartite: the first-formed (proximal) part is more or less triangular in outline, consisting of two arms perpendicular to each other on a heel-like pedicel; the second-formed (distal) part is fusoid or allantoid, connected dorsally to the proximal part. Conidial secession is schizolytic

Campylospora leptosoma Marvanová \& Laichmanová sp. nov.

Figs 3-22

MycoBank: MB 800958

Etymology $-\lambda \varepsilon \pi \tau o \sigma($ Greek $)=$ narrow, $\sigma o \mu \alpha=$ body; refers to the rather slender parts of the compound conidial body when compared to the rest of Campylospora species.

Holotype: PRM 860469

Ex-holotype: CCM F-15308

Asexual fungi, hyphomycetes. Colonies on MEA 2\% moderately fast growing, reaching 32-40 mm in diam. after 30 days at $22-24^{\circ} \mathrm{C}$, vinaceous buff, radially furcate, indistinctly zonate, paler at the margin, in some isolates with a greyish marginal zone, centre elevated, aerial mycelium abundant, 

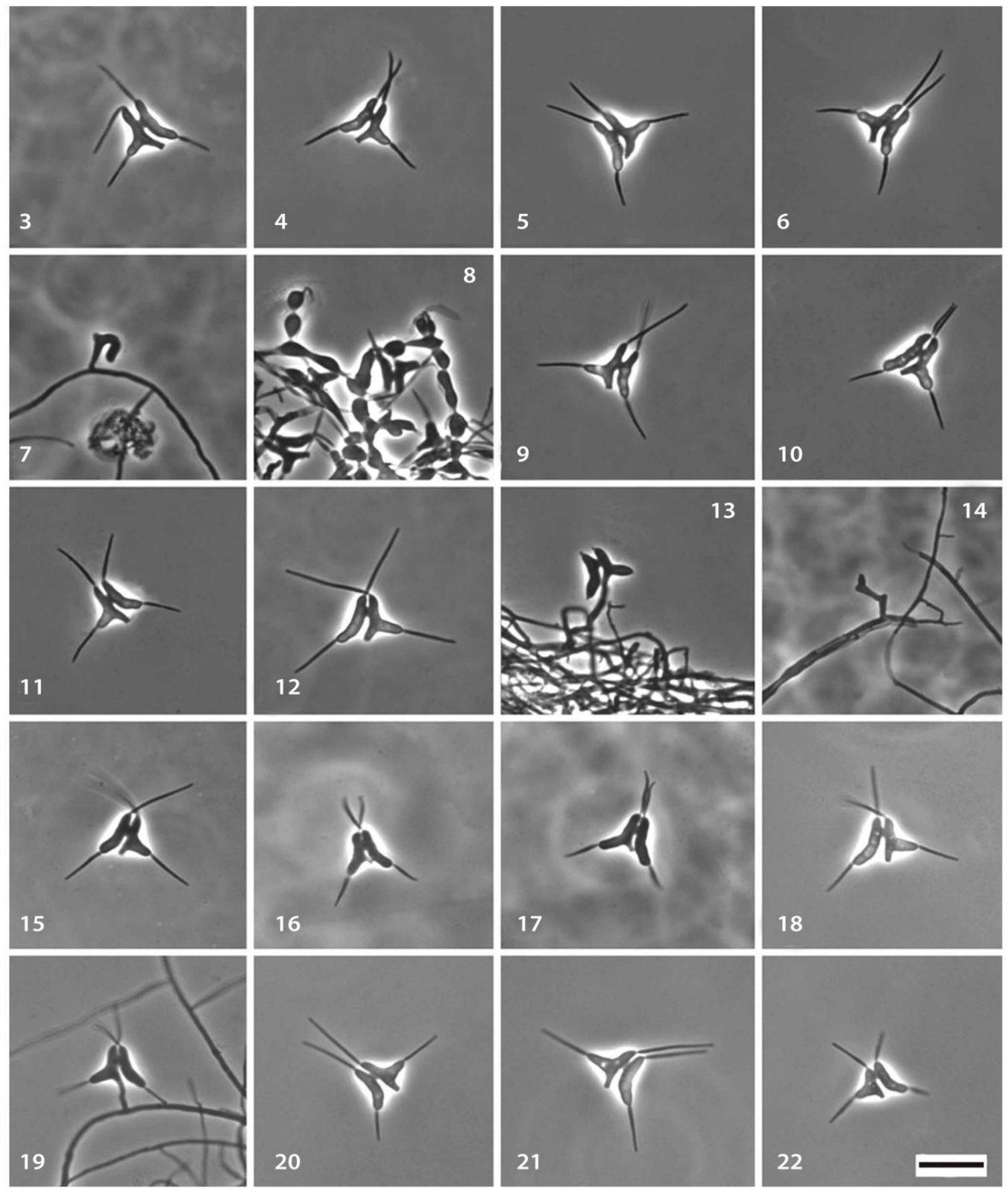

Figs 3-22 - Campylospora leptosoma. CCM F-15308 (ex-holotype). 3-6, Mature conidia. 7, Conidial primordium. 8, Inflated cells. CCM F-16008. 9-11, Mature conidia. CCM F-15408. 12, Mature conidium. 13, Developing conidium producing appendages. 14, Spent conidiophore with sympodial proliferations. BCRC 33290. 14, Mature conidium. CCM F-11508. 15-19, Mature conidia with shorter, fusoid appendages. CCM F-10510. 20-22, Mature conidia. Scale bar = 20 $\mu \mathrm{m}$.

whitish, cottony, often with scattered fine funicles mainly in the centre of the colony, occasionally with more coarse fascicles near the margin; reverse below inoculum mostly ochreous or darker (honey or isabelline) paling towards margin, but sometimes with greyish sepia or grey olivaceous or fawn zone at the very margin, often with a few dark, irregularly scattered spots ca $2-3 \mathrm{~mm}$ in diam. Hyphae hyaline, thin-walled to pale brown with slightly thickened walls, septate, branched, 1-3 $\mu \mathrm{m}$ wide, with numerous mostly narrow clavate hyphopodia $6-15 \times 1-1.5 \mu \mathrm{m}$, sometimes with an apical, simple or branched filamentous extension. Pale brown, globose to ellipsoidal or elongate, rarely irregularly inflated cells $3-20 \times 2-7 \mu \mathrm{m}$ with slightly thickened walls appear in chains or clusters in older cultures; in CCM F-15308 there are hyaline to dark microsclerotia submerged in agar, ca 170-400 $\mu \mathrm{m}$ across, composed of globose to ellipsoidal, short clavate or cylindric thicker- 
walled brown cells $10.5-32 \times 10-17 \mu \mathrm{m}$. Conidiophores lateral or rarely terminal or intercalary, cylindrical or somewhat nodose, mostly simple or rarely sparsely branched, 3-70 $\times 1-2.5 \mu \mathrm{m}$. Conidiogenous cells integrated, proliferations rarely distinctly sympodial and then denticulate, scars flat, in aged conidiophores often indistinct. Conidia form abundantly after submerging pieces of culture into standing distilled water or less abundantly on aerial mycelium. The conidium development follows the pattern described for the genus. The conidial primordium in the "crozier" stage is relatively narrow, 3-4 $\mu \mathrm{m}$ across at the first-formed septum in the point of bending. Mature conidia are septate, slightly constricted at septa (cells of the conidial body in aged cultures may be distinctly inflated); the triangular part is 3-4 septate, $6-10 \times 11-23 \mu \mathrm{m}$, the heel-like pedicel is typically cylindric, widened only just below the foot of the lateral arm, 1-1.7 $\times 2-5 \mu \mathrm{m}$; the allantoid part is 3(4) septate, $9-19 \times 3-4.5 \mu \mathrm{m}$; conidial end cells are apically rounded or rarely conoid, the two juxtaposed distal ones often semi-dome shaped with adjacent sides flattened and parallel; each end cell bears a single appendage; appendages are parallel-walled or slightly tapering distally, 9-35 $\times 1-1.5 \mu \mathrm{m}$, typically distinctly constricted or rarely cylindrical at insertion, straight or gently curved, mostly terminal, but on the distal conidial ends sometimes subterminal, crossed or diverging, rarely parallel or abruptly recurved. Top or bottom view of the conidial body is fusoid. Conidial hilum is flat or somewhat bulged, slightly thickened; conidial secession is schizolytic. Sexual state: Unknown.

Holotype locality - Malaysia, Banjaran Titi Wangsa Mountains (Cameron Hills), Bukit Fraser (Fraser's Hill) town, small unnamed stream with sandy to gravely bed and fast running water, c. $1400 \mathrm{~m}$ alt.

Cultures examined - CCM F-15308; CCM F-15408; CCM F-15908; CCM F-16008, isolated by L. Marvanová from a decaying submerged leathery leaf of a dicot plant collected at the holotype locality by I. Sedláček, 15.4.2008; CCM F-10410; CCM F-10510; CCM F-11010; CCM F-11410; CCM F-11510; CCM F-12010; CCM F-12110; CCM F-12210; CCM F-12310, Malaysia, (northwest Borneo), Sabah, Crocker Mountain Range, forest stream in the vicinity of the village Kiangaran, c. $800 \mathrm{~m}$ alt., isolated by L. Marvanová from submerged dicot tree leaves coll. by I. Sedláček 30.4.2010; BCRC 33290, China, Taiwan, Wulai, S.S. Tzean.

The isolate BCRC 33290 shows only minor differences from the Malaysian isolates, namely its lower arm of the triangular part is wider at the base and the heel-like pedicel is shorter and broader.

Conidia considered by us to belong to this species, were seen in stream foam samples: Austria, Weinviertel, river Ybbs near the town Lunz am See (Marvanová \& Gulis 2000, as Campylospora sp.); South African republic, Natal, Royal Natal National Park, Devil's Hoek River and Vemvaan River (Webster et al. 1994, Fig. 3S, as Campylospora sp).

Unpublished records from stream foam, documented by drawings of conidia: Slovak Republic, Little Carpathian Mountains, right tributary of the unnamed stream along the road between the villages Pernek and Pezinok, 15.4. 1968 (Fig. 24), L. Marvanová; Stupavský potok stream near the settlement Košiariská, 15.10 .1982 (Fig. 23), L. Marvanová; Ecuador, Province Napo, Río Cedro river ca $50 \mathrm{~m}$ above the confluence with the river Río Oyacachi, in foam, 4.9.1999 (Fig. 25), coll. Z. Palice, ident. L. Marvanová.

\section{Comments}

The first illustration based on pure culture with conidia assignable to C. leptosoma, is by Matsushima (1980, Fig. 7, 1-2, from leaves of Canna generalis, terrestrial habitat, Taiwan).

Unfortunately the fungus was misidentified as Campylospora filicladia, No data on culture character or on morphology is given, but the morphology and dimensions of conidia derived from the drawings fit well into the range seen in C. leptosoma. In Matsushima's drawing the conidial cells appear distinctly inflated - such shapes have been seen in our isolates of C. leptosoma only after long submergence in standing water. A phialidic andromorph ('Phialophora form'), reported in his culture on $\mathrm{V}-8$ juice agar, was not seen in our isolates. A second, not illustrated report referring to C. filicladia from Taiwan is by the same author from Australia (Matsushima 1989, 


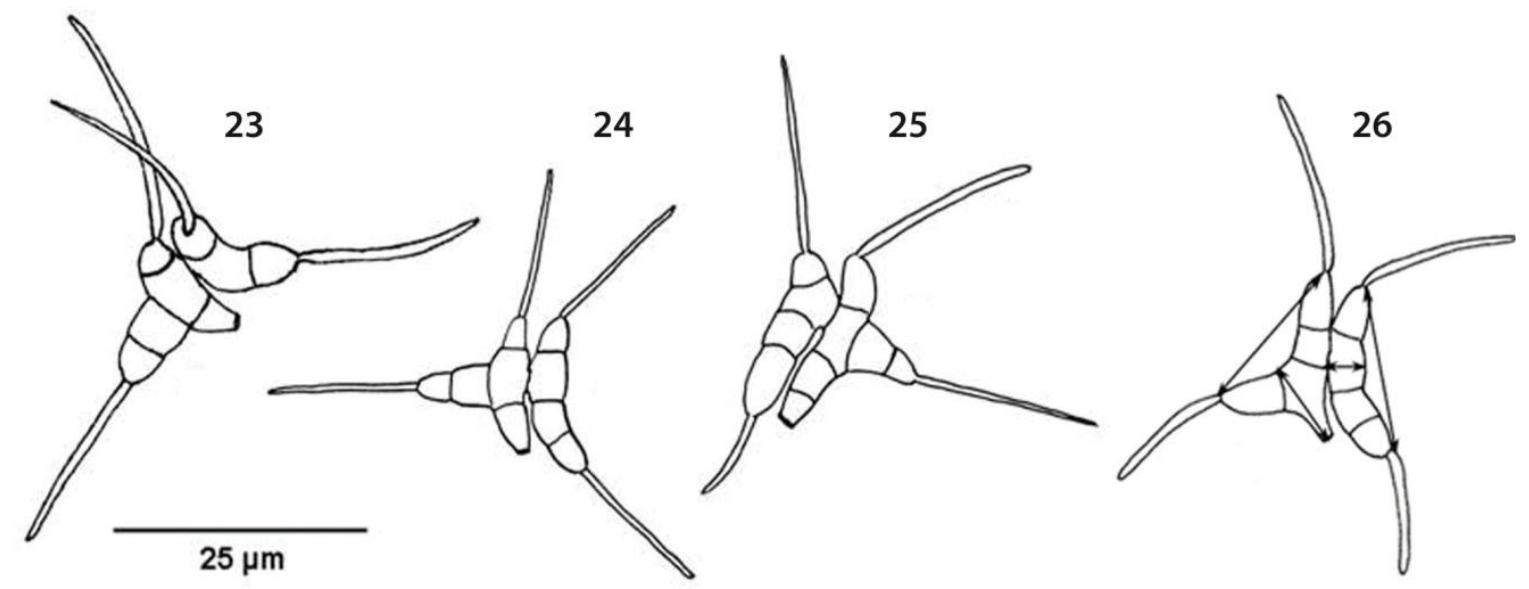

Figs 23-26 - Conidia of Campylospora leptosoma from various countries. 23, 24. Slovak Republic. 25. Ecuador. 26. Malaysia. Note the abscissae showing how the conidial body is measured.

Queensland, on decaying tree leaf from terrestrial habitat). A third record (Matsushima 1993, again as $C$. filicladia, collections from Peru and Ecuador) is accompanied by a photo, showing typical conidia of $C$. leptosoma ( the geographical origin - Peru or Ecuador - of the illustrated conidia is not specified).

There are several illustrations of conidia from various countries, which also may be considered as representing Campylospora leptosoma, although sometimes misidentified as other species: here we mention the most similar to our isolates: Spain: Descals et al. (1977, Fig. 3 I,O), Descals 1998 (Fig. 13 I,J), both as Campylospora sp., cited later as C. filicladia in Descals \& Rodriguez Pérez (2002); Thailand: Tubaki et al. (1983, Fig. 17, as Campylospora sp.); Austria: Regelsberger et al. (1987, Fig. 2 D1, D2, as '?C. chaetocladia'); Puerto Rico: Betancourt et al. (1987, Fig. 5, as C. parvula); France: Descals \& Chauvet (1992, Fig. 4 M,N, as Campylospora sp.); China (Hong Kong): Chan et al. (2000, Fig. 1,1, as C. filicladia); Venezuela: Smits et al. (2007, Fig. 1a, as C. chaetocladia); India: Patil \& Borse (2011, Plate 1 Fig. 2, as C. filicladia); Brazil: Fiuza \& Gusmăo (2013, Fig. 1, 5, as Campylospora sp.). Although pure cultures are known from Malaysia and China (Taiwan) only, the above references suggest that C. leptosoma is distributed worldwide.

Campylospora chaetocladia Ranzoni, Farlowia 4: 373, 1953

Figs 27-29

Colonies on MEA 2\% moderately fast growing, reaching 25-30 mm diam. in 20 days at laboratory temperature in dark, whitish to pale isabelline, eventually with yellowish hue; aerial mycelium abundant, fluffy, with occasional knots of hyphae, reverse pale isabelline. Hyphae 1-2 $\mu \mathrm{m}$ wide, hyaline and thin-walled or with slightly thickened brownish walls up to $4 \mu \mathrm{m}$ wide, inflated cells intercalary, subglobose to elongate, 4-10 $\times 2.5-4 \mu \mathrm{m}$, often in short chains or interwoven loose clusters 50-65 $\mu \mathrm{m}$ across. Hyphopodia rare, subglobose to elongate, ca $2-3 \times 3-5$ $\mu \mathrm{m}$. Conidiophores simple, lateral up to $80 \times 2-2.5 \mu \mathrm{m}$ or terminal, not differing from vegetative hyphae. Conidiogenous cells integrated, somewhat nodose, rarely distinctly sympodial. Conidial primordia ca 3.5-4 $\mathrm{mm}$ across at the first formed septum, the apical cell usually strongly curved adaxially. Mature conidia: Triangular part 3-4-celled, 9-14 x 15-25 $\mu \mathrm{m}$, heel-like pedicel 3-6 $\times$ 2-4 $\mu \mathrm{m}$, sometimes delimited by a septum; fusoid part 2-3-celled, 17-25 $\times 4.5-6.5 \mu \mathrm{m}$, straight or slightly curved outwards and often perpendicular to the triangular part, conidial end cells conical, bearing integrated appendages $29-56 \times 1.5-2 \mu \mathrm{m}$, tapering distally to ca. $1 \mu \mathrm{m}$, sometimes 


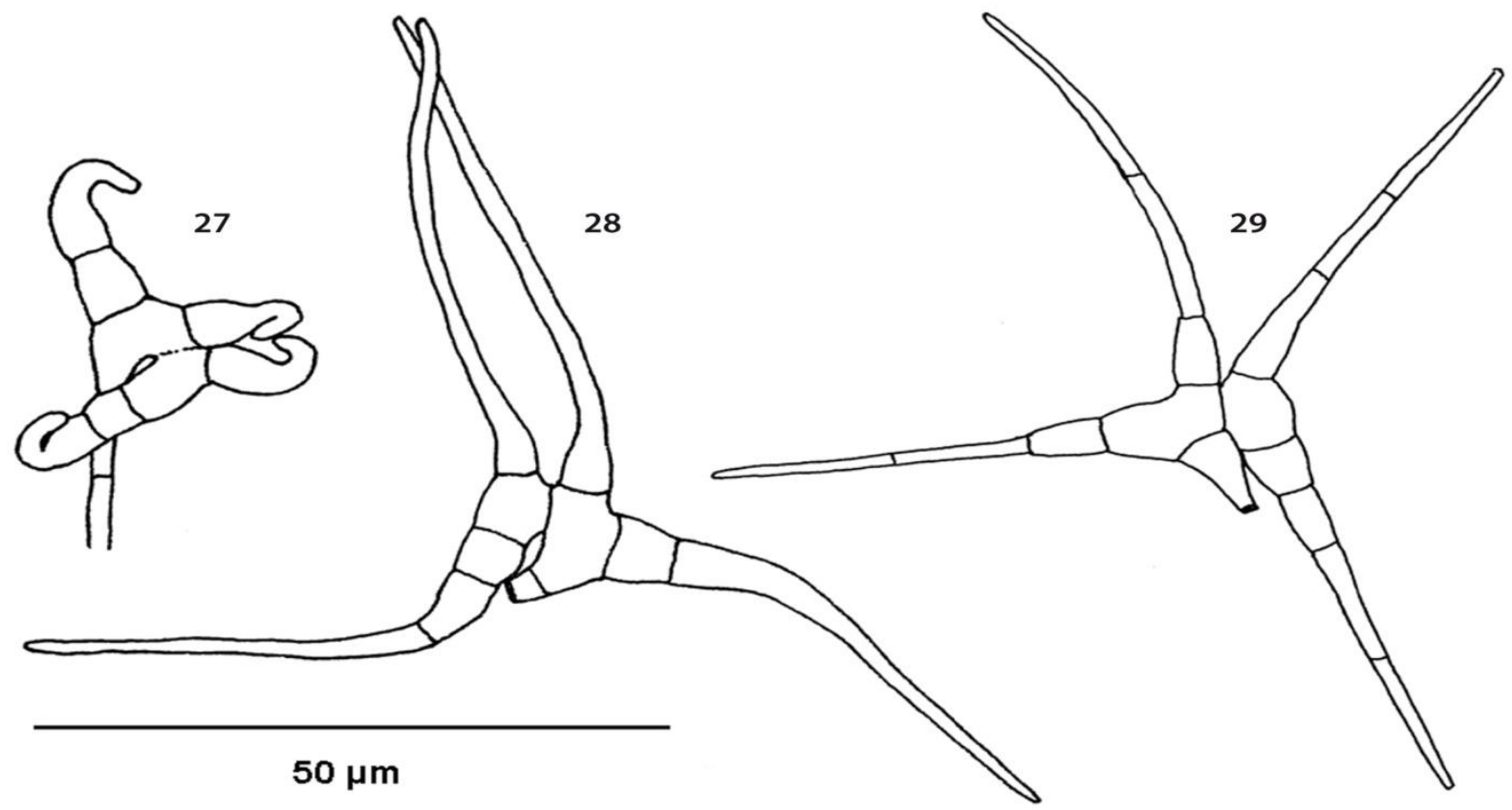

Figs 27-29 - Campylospora chaetocladia. CCM F-17708. 27. Early stage of conidium development, showing the strongly recurved appendages typical for this species. 28. Mature conidium. CCM F-10610. 29. Mature conidium.

delimited by a septum, proximal appendages usually somewhat shorter. During development the appendages are strongly bent inwards, stretching before conidial release. Sexual state: Unknown.

Living cultures: CCM F - 17708 (representative strain), Greece (Corfu), Benitses, unnamed stream originating from a spring in a hillock above the village, on decaying tree leaves, 19.6.2008 L. Marvanová; CCM F-10610, CCM F-10710, CCM F-10810, Malaysia (northwest Borneo), Sabah, Crocker Mountain Range, in the vicinity of the village Tambunan, on decaying dicot tree leaves in a forest stream, ca $800 \mathrm{~m}$ elevation, 30.4.2010, coll. I. Sedláček, isol. L. Marvanová. Herbarium material: IMI 239542, India, Mannanur Forest, leaf litter in a pond, 1978, C. Manohara Chary OUFH-2; conidial appendages only 10-22.5 $\mu \mathrm{m}$ long.

\section{Comments}

C. chaetocladia was described from North America (California) in 1953, when designation of type specimen was not obligatory for valid publication. We were unable to locate any material left by Prof. V. Ranzoni, therefore we base the lectotype on the drawing, published in the protologue. Neotypification and epitypification would be desirable with a specimen from North America.

C. chaetocladia is reported worldwide, predominantly from warm or tropical climate, e.g. Africa (Ingold 1958); South America (Nilsson 1962), Fiuza \& Gusmão 2013); Australia (Cowling 1963); New Guinea (Tubaki 1965); Malaysia (Nawawi 1974); Pakistan (Iqbal et al. 1980).

Campylospora filicladia Nawawi, Trans Br. mycol. Soc. 63: 604, 1974

Figs 30-33

Lectotype - IMI 181305 here designated.

Epitype - PRM 860470 here designated. Malaysia (northwest Borneo), Sabah, Crocker Mountain Range, in the vicinity of the village Kiangaran, on decaying frondose leaves in a forest stream, 30.4.2010 coll. I. Sedláček, isol. L. Marvanová.

Ex-epitype: CCM F-10310 
Colonies on MEA $2 \%$ moderately fast growing, reaching $25-30 \mathrm{~mm}$ diam. in 25 days at laboratory temperature in dark, pale olivaceous grey, radially furcate to varying depth, rarely plane, margin entire, centre elevated, greyish buff, reverse greyish, partly with yellowish hue, in one isolate (CCM F-10310) fuscous black; aerial mycelium finely downy to cottony, becoming finely funiculose towards margin, whitish, in some isolates indistinctly zonate (in CCM F-10310 with a ca $2 \mathrm{~mm}$ wide dark grey zone between the colony centre and the margin). On $0.5 \%$ MEA the colony is plane, with sparse aerial mycelium, finely granular, whitish with pale rosy hue, sporulating on agar surface, reverse colourless. Hyphae hyaline, 0.8-1.2 $\mu \mathrm{m}$ wide, thin-walled, or fuscous, 1.5-2 $\mu \mathrm{m}$ wide, with slightly thickened walls; hyphopodia narrow clavate to cylindrical, $5-13 \times 0.7-1.5 \mu \mathrm{m}$; inflated cells fuscous, with slightly thicker walls, single or more often in chains, globose to elongate and then sometimes biscuit-shaped (with rounded ends and narrowed central part), $6-11 \times 3-6 \mu \mathrm{m}$. In the primoculture on DRBC agar small hyaline microsclerotia were observed in one isolate, appearing in a ring near the colony margin; they were soft, more or less globose, ca $250 \mu \mathrm{m}$ in diam. After subculturing on the same medium or on MA $0.5 \%$ they did not form. Conidiophores predominantly lateral, cylindrical, slightly tapering upwards or irregularly nodose, 6-31 × 1-3 $\mu \mathrm{m}$, simple or sparsely branched. Conidiogenous cells terminal, integrated, often nodose, rarely distinctly sympodial. Conidial primordia $2.5-4 \mu \mathrm{m}$ wide near the middle. Mature conidia: Triangular part (2)-3 septate, $4.5-7.5 \times 9-12 \mu \mathrm{m}$, heel-like pedicel mostly short, $0.5-2.5 \times 1-2 \mu \mathrm{m}$, hilum slightly thickened; allantoid part 9-13 $\times 3-4.5 \mu \mathrm{m},(1)-3$ septate, distal conidial end cells are apically rounded, often semi-dome shaped, proximal end cells obtusely rectangular, but they may appear rounded, depending on the actual position of the conidium on the microscopic slide. Top or bottom view of the conidial body is more or less rectangular. Appendages hair-like, arising from a minute conical outgrowth, inserted subapically and often excentrically on the conidial end cells. The upper ones are 7-17 (35), the lower 6-11 $\mu \mathrm{m}$ long and 0.3-0.7 $\mu \mathrm{m}$ wide. Sexual state: Unknown.

Specimens examined. Living cultures: CCM F-10010, CCM F-10110, CCM F-10210, CCM F-11110, CCM F-11210, CCM F-11710, CCM F-11810, CCM F-11910, CCM F-12410, the same locality and collector as for epitype. Herbarium material: IMI 181305.

\section{Comments}

Nawawi (1974, p. 605) published the type specimen as "Typus IMI 181305 et UM/G23". According to the Melbourne ICN Code (McNeill et al.2012), these two deposits are syntypes (Art. 9.5), hence we selected here one of them as lectotype. The authentic living culture IMI 181305 deposited by A. Nawawi which could serve for epitypification, is unavailable from CABI (Dr.M.J. Ryan, e-mail information from 28.5.2012).

All our isolates originate from one locality and do not differ from each other in ITS sequences. Morphologically they conform with IMI 181305.

Although conidia are documented also from Japan (Miura 1974, Fig. 4), New Zealand (Aimer \& Segedin 1985, Fig. E); Puerto Rico (Santos-Flores \& Betancourt-López (1997, Figs 33,34), Brazil (Fiuza \& Gusmăo 2013, Fig. 1, 1), this species is rarely isolated; in pure culture it is known with certainty only from Malaysia, the non-Malaysian records were often confused with $C$. leptosoma (see above).

Campylospora parvula Kuzuha, J.Jap. Bot. 48: 220, 1973

Figs 34-37

Lectotype: Fig. 1 (Jour. Jap. Bot. 48, p. 221, 1973), here designated.

Epitype: PRM 860471 here designated. Malaysia, Banjaran Titi Wangsa Mountains (Cameron Hills), Bukit Fraser (Fraser's Hill) town, small unnamed stream with sandy to gravely bed and fast running water, ca 1400 m a.s.1., 15.4.2008 coll. I. Sedláček, isol. L. Marvanová.

Ex-epitype: CCM F-14908

Colonies of the Malaysian isolates on MEA 2\% moderately fast growing, reaching 35-40 $\mathrm{mm}$ diam. in 25 days at laboratory temperature in dark, pale mouse grey with purplish hue, even or 
irregularly bumpy, aerial mycelium abundant, cottony with some funicles, margin low, entire; reverse mouse grey to black, with a narrow, greyish sepia margin. Hyphae 1-4 $\mu \mathrm{m}$ wide, hyaline, thin-walled, some with brownish thicker walls, these rarely containing single inflated cells ca $4 \times 5$ $\mu \mathrm{m}$. Hyphal funicles up to $12 \mu \mathrm{m}$ across. Hyphopodia elongate, with obtuse apex or narrow clavate, 3-8 $\times 1-2.5 \mu \mathrm{m}$, sessile or on thin pedicels. Conidiophores cylindrical, terminal and then mostly somewhat wider than the supporting hypha, or lateral, 15-34 $\times 1.5-2 \mu \mathrm{m}$. Conidiogenous cells terminal, integrated, proliferation not seen by us, but illustrated as sympodial (Matsushima 1980, Fig.8). Conidial primordia relatively plump, ca $5 \mu \mathrm{m}$ across at the point of bending. Mature conidia: Triangular part 8-11 ×9-15 $\mu \mathrm{m}$, heel-like pedicel mostly short and wide, $2-3 \times 2.5-3.5$ $\mu \mathrm{m}$, base truncate, with a slightly thicker hilum; fusoid part 11-16 $\times 4.5-6 \mu \mathrm{m}$; conidial end cells shortly conoid, appendages slightly widened or cylindrical at insertion; the appendage on the distal end cell of the triangular part finger-like, ca $4 \times 1-2 \mu \mathrm{m}$, apical and more or less strongly bent or subapical, perpendicular to the supporting cell, rarely straight, appendages on remaining conidial ends apical, thin, 3-7 $\times 0.7-1 \mu \mathrm{m}$, straight or slightly curved. The endophytic isolate from U.K. produces beige colonies with whitish, lanose aerial mycelium, reverse fuscous, sienna in the centre.

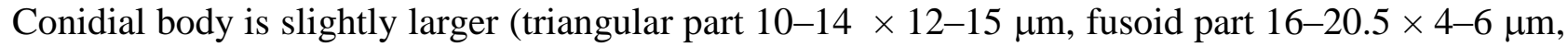
filiform appendages are 7-12 $\mu \mathrm{m}$ long, finger-like appendage apical, curved at right angle, or subapical. Sexual state: Unknown.

Living cultures: CCM F-13208, CCM F-13708, CCM F-14308, CCM F-146 08, CCM F15008 , the same locality and collector as for the epitype, from submerged leathery leaf of dicotyledonous woody plant isol. L. Marvanová; CCM 8044, UK, England, Devon, Exeter, bank of the Exeter Canal, isolated as endophyte from root bark of Alnus glutinosa, P. J. Fisher 223. Herbarium material: Japan, Nishitama, Tokyo, on submerged leaves of dicotyledonous plants, TNS, holotype, Shizu Kuzuha (received directly from Mrs. Kuzuha in 1984). It is recently reported unknown in TNS (e-mail message by Tsuyoshi Hosoya, curator in the National Museum of Nature and Science). Since no ex-holotype culture or authentic culture has been located in registered culture collections we establish a lectotype, supported by epitype from our Malaysian isolate.
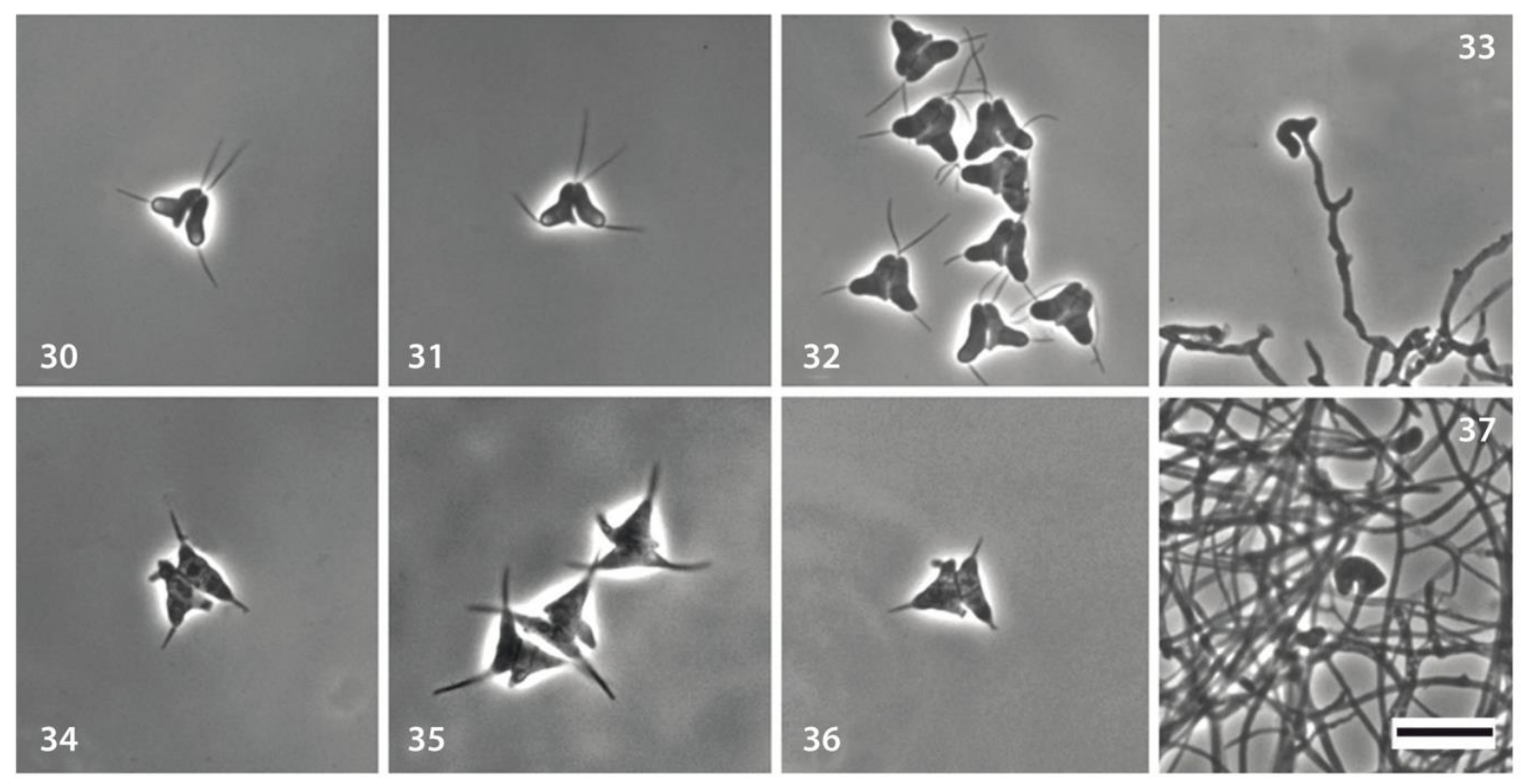

Figs 30-33 - Campylospora filicladia. 30, 31. CCM F-10210, 32. CCM F-11110. Mature conidia. 33. Conidial primordium. Figs 34-37 - Campylospora parvula. 34, 36. CCM F-14308, CCM F14908 (ex-epitype). Mature conidia. 35. CCM 8044. Conidia from endophytic isolate (note the longer appendages). 37. CCM F-15008. Conidial primordium (note its robustness in contrast to those of C. leptosoma and C. filicladia). Scale bar $=20 \mu \mathrm{m}$. 
C. parvula was isolated also in Taiwan (Matsushima 1980) and the UK (Fisher \& Petrini 1989); conidia from water are reported from various places of the world (Fiuza \& Gusmăo 2013), but owing to some misidentifications (e.g. Betancourt et al. 1987, see under C. leptosoma), the reports have to be taken with caution. Colony was neither described in the protologue, nor by other authors reporting on this species.

Nawawi (1974) called attention to the discrepancy between the illustration of the fingerlike conidial appendage in the protologue (Kuzuha 1973, Fig. 1 G,I) - bent backwards - and his own observation made on the microscopic slide with conidia sent to him by S. Kuzuha where he saw these appendages inserted subapically, in one conidium with constriction at the base (his Fig. 1M). This was illustrated also by Matsushima (1980, Fig. 8) on the material from Taiwan on Canna generalis leaves, but among conidia with subapical finger-like appendages he depicts three with apical appendages. Strongly recurved short apical appendage is depicted also in Descals \& Chauvet (1992, Fig. 4, O). In our isolates we observed considerable variation of that appendage - both morphologies were possible within the same isolate and straight short apical appendages also occurred. The relative thickness of $C$. parvula conidia obscures somewhat the very details of their morphology under the light microscope.

\section{Campylospora sp.}

Figs 38, 39

Besides the above species we observed conidia which according to our opinion belong to another new species of Campylospora. Although we isolated them into pure culture, all details of conidiogenesis were not seen and the cultures were lost. To encourage mycologists to look for them at similar localities, we present at least a brief description of detached conidia: Triangular part 9-13 $\times 12.5-20 \mu \mathrm{m}$, often dictyoseptate, fusoid part 16-22 × 5.5-7.5 $\mu \mathrm{m}$, conidial end cells conoid, appendages apical, parallel-walled, base cylindrical or only slightly constricted; distal appendages 15-26 $\mu \mathrm{m}$, proximal 12-18 $\mu \mathrm{m}$ long, both 1-1.5 $\mu \mathrm{m}$ wide. Cells of conidial body contain a few vacuoles. These conidia are similar to those of Campylospora parvula, but the conidial body is larger, the appendages are all filiform, distinctly longer than in C. parvula.

Specimens examined (permanent microscopic preparations from pure cultures): CCM F12510, CCM F-12610, CCM F-12810, Malaysia (northwest Borneo), Sabah, Crocker Mountain Range, in the vicinity of the village Kiangaran, on decaying frondose tree leaves in a forest stream, 30.4.2010 coll. I. Sedláček, isol. L. Marvanová.
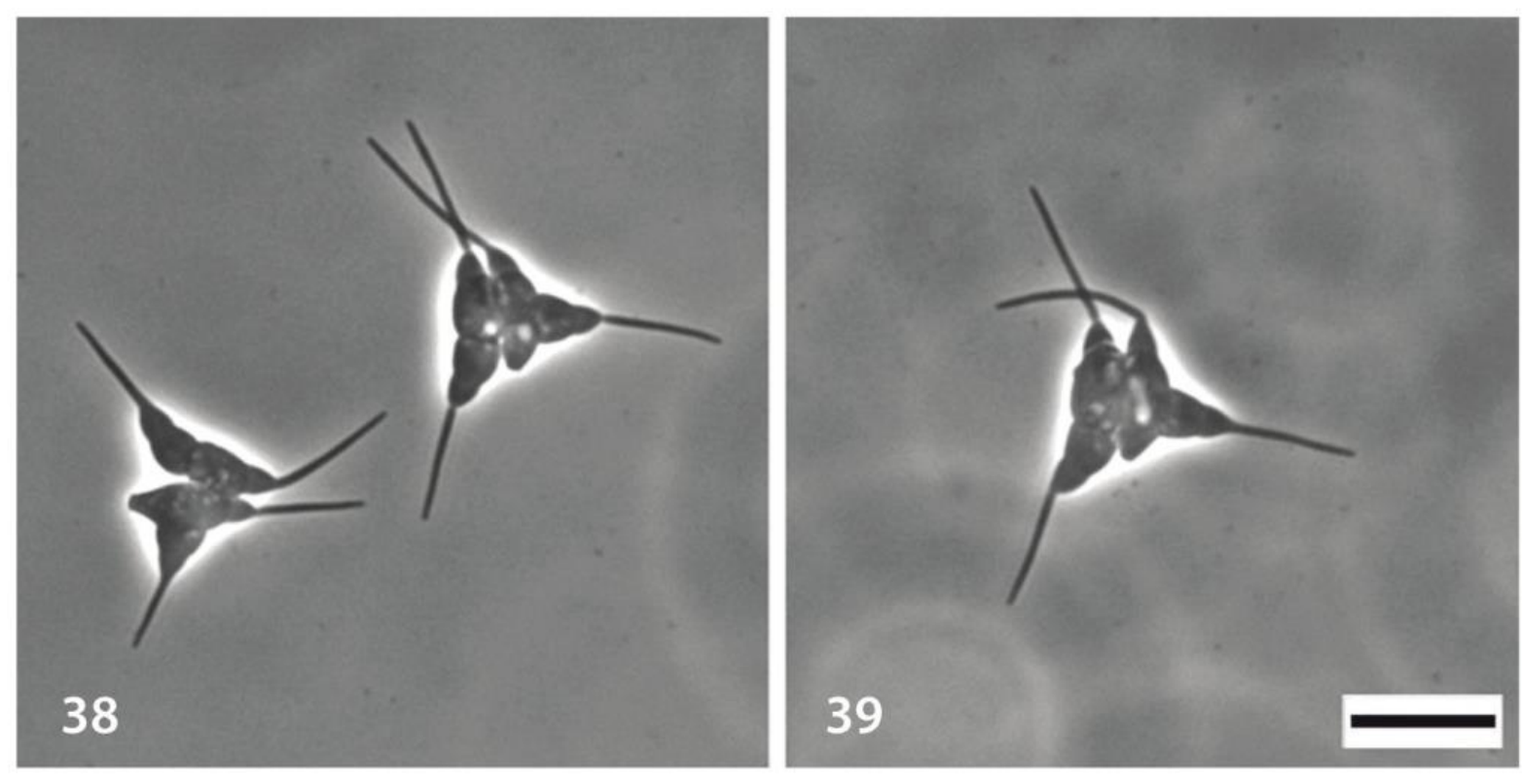

Figs 38-39-Campylospora sp. Mature conidia. Scale bar $=20 \mu \mathrm{m}$. 


\section{Key to species}

[1] Triangular part of conidial body $9-11 \times 15-20 \mu \mathrm{m}$, fusoid part 17-25 $\times 5-6 \mu \mathrm{m}$, appendages integrated with the conidial end cells, $29-56 \times 1.5-2 \mu \mathrm{m}$ C. chaetocladia

[1] Parts of conidial body smaller, appendages discrete, shorter

[2] Terminal cell of triangular part bearing a perpendicular finger-like appendage up to $3 \times 1 \mu \mathrm{m}$, remaining end cells conic, with thin terminal appendages up to $12 \times 0.4-0.8 \mu \mathrm{m}$............. C. parvula

[2] End cells apically rounded, all appendages uniform, longer than $12 \mu \mathrm{m}$.

[3] Triangular part 4.5-7 ×9-11.5 $\mathrm{m}$, allantoid part 9-12.5 $\times 3-4 \mu \mathrm{m}$, appendages hair-like, arising subapically from a minute conic projection on conidial end cells C. filicladia [3] Triangular part 6-10 × 11-23 $\mu \mathrm{m}$, allantoid part 13-18 $\times 3-4 \mu \mathrm{m}$, appendages apical or subapical, typically constricted at base..... C. leptosoma

\section{Discussion}

This is the first attempt to reveal intrageneric relationships of Campylospora with the aid of rDNA analysis. We are aware of relative paucity and little geographic diversity of our sampling, but Campylospora conidia occur in low percentages in samples from streams and their distinct morphology eliminates the necessity of establishing pure cultures for routine identification, hence isolates are rarely available.

Campylospora appears monophyletic, close affinity to some terrestrial genera of Hypocreomycetidae is evidenced by BLAST search ( Calonectria, Colletotrichum, Volutella).

The species resolution of $C$. chaetocladia, $C$. filicladia and $C$. parvula is congruent with their morphology. In contrast, the five strains of $C$. leptosoma are split into two clades: one forms a well supported sister clade with $C$. parvula, the other an unsupported sister clade with $C$. chaetocladia. The separation of $C$. leptosoma into two clusters does neither correspond to the geographic origin of the strains, nor to conidial morphology. Under these circumstances we prefer the species concept based on morphology. More studies from other, more geographically dispersed localities and sequencing of additional genetic loci may help to resolve the problem. Also, existence of cryptic species may not be excluded.

Illustrations of Campylospora conidia prior to the formal description of the genus appeared in the literature in the early fifties (Ingold \& Ellis 1952, Fig. 1g, unnamed). The conidia are similar to those of $C$. leptosoma, but the appendages are unconstricted at the base and too short to match $C$. leptosoma. Some drawings of conidia published by Nawawi (1985, Fig. 7) from Malaysia and by Santos-Flores \& Betancourt-López (1997, Fig. 37) from Puerto Rico, are probably also undescribed species, they differ by conical end cells of the conidial body with long thin appendages without constrictions at insertion.

Ingold \& Cox (1957) saw similarity between Campylospora chaetocladia and Tripospermum camelopardus in the early stage of conidial morphogenesis and appendage disposition. However, phylogenetic affinity of these taxa is not supported in our study. Tripospermum spp. belong in Capnodiales, and T. myrti was recently placed in a relatively well supported cluster of Teratosphaeriaceae (Ruibal et al. 2009, Dothideomycetes).

Campylospora species seem not to be rheofilic; they sporulate abundantly in standing distilled water, often on the water/air interface or above the water level, C. filicladia and $C$. leptosoma also on agar surface without submergence. The latter was reported also from terrestrial leaf litter (Matsushima 1980, 1989, 1993).

The main bulk of information on distribution of individual species originates from studies of biodiversity in various kinds of waters or from ecological studies, based on microscopic examination of natural samples or on conidia obtained in laboratory from leaves previously colonized in water. Unfortunately, owing to the relatively frequent confusion in identification, the true distribution of individual species and their ecological requirements are not well known. 


\section{Acknowledgment}

Financial support of this study to the first author by the Czech Collection of Microorganisms is appreciated. The authors thank to Ivo Sedláček for collecting the material, to Jarmila Marvanová for the final layout of the manuscript and to Christiane Baschien for valuable comments.

\section{References}

Aimer RD, Segedin BP. 1985 - Some aquatic hyphomycetes from New Zealand streams. New Zealand Journal of Botany 23, 273-299.

Betancourt C, Cruz J, García J. 1987 - Los hifomicetos acuáticos de la quebrada Doña Juana en el bosque estatal de Toro Negro, Villalba, Puerto Rico. Caribbean Journal of Science 23, 278-284.

Chan SY, Goh TK, Hyde KD. 2000 - Ingoldian fungi in Hong Kong. Fungal Diversity 5, 89-107.

Cowling SW. 1963 - The aquatic hyphomycetes of Eastern Australia. BSc Thesis, University of New England. Armidale, NSW, Australia, 93 pp.

Descals E. 1998 - Streamborne fungi from Karrantza (Basque Country) and surroundings. Boletin de la Sociedad de Historia Natural de Baleares 41, 191-219.

Descals E, Chauvet É. 1992 - Diversité des champignons Ingoldiens de quelques rivières du sudouest de la France. Nova Hedwigia 54, 83-96.

Descals E, Rodríguez Pérez J. 2002 - Bases corológicas de Flóra Micológica Ibérica. Números 1933-2069, Madrid.

Descals E, Sanders PF, Ugalde UO. 1977 - Hifomicetos ingoldianos del País Vasco. Munibe 29, 237-260.

Felsenstein J. 1985 - Confidence limits on phylogenies: an approach using the bootstrap. Evolution 39, 783-791.

Fisher PJ, Petrini O. 1989 - Two aquatic hyphomycete species as endophytes in Alnus glutinosa roots. Mycological Research 92, 367-368.

Fiuza PO, Gusmăo LFP. 2013 - Ingoldian fungi from semiarid Caatinga Biome of Brazil. The genus Campylospora. Mycosphere 4, 559-565.

Gardes M, Bruns TD. 1993 - ITS primers with enhanced specificity for basidiomycetes application to the identification of mycorrhizae and rusts. Molecular Ecology 2, 113-118.

Ingold CT. 1967 - Spores from foam. Bulletin of the British Mycological Society 1(2), 60-63.

Ingold CT. 1958 - Aquatic hyphomycetes from Uganda and Rhodesia. Transactions of the British Mycological Society 41, 109-114.

Ingold CT, Cox VJ. 1957 - On Tripospermum and Campylospora. Transactions of the British Mycological Society 40, 317-321.

Ingold CT, Ellis EA. 1952 - On some hyphomycete spores, including those of Tetracladium maxilliformis, from Wheatfen. Transactions of the British Mycological Society 35, 158-161.

Iqbal SH, Bhatty SF, Malik KS. 1980 - Freshwater hyphomycetes of Pakistan. Bulletin of Mycology 1, 1-25.

Jukes TH, Cantor CR. 1969 - Evolution of protein molecules. In: Munro HN (ed) Mammalian Protein Metabolism III, pp. 21-132, Academic Press, New York.

Kuzuha S. 1973 - Two new species of aquatic Hyphomycetes. Journal of Japanese Botany 48, 220224.

Marvanová L, Gulis VI. 2000 - Notes on aquatic hyphomycetes and streamborne spora from Austria. Österreichische Zeitschrift für Pilzkunde 9, 125-140.

Matsushima T. 1980 - Saprophytic Microfungi from Taiwan. Part I. Hyphomycetes. Published by the author, Kobe.

Matsushima T. 1989 - Matsushima Mycological Memoirs No. 6. Matsushima Fungus Collection, Kobe. 
Matsushima T. 1993 - Matsushima Mycological Memoirs No. 7. Matsushima Fungus Collection, Kobe.

McNeill J, Barrie FR, Buck WR, Demoulin V, Greuter W, Hawksworth DL, Herendeen PS, Knapp S, Marhold K, Prado J, Prud'homme van Reine WF, Smith GF, Wiersema J, Turland NJ (eds). 2012 - International Code of Nomenclature for algae, fungi and plants (Melbourne Code). Regnum vegetabile No. 154. Königstein: Koeltz Scientific Books.

Miura K. 1974 - Stream spora of Japan. Transactions of the Mycological Society of Japan 15, 289308.

Nawawi A. 1974 - A new Campylospora. Transactions of the British Mycological Society 63, 603-606.

Nawawi A. 1985 - Aquatic hyphomycetes and other water-borne fungi from Malaysia. Malayan Nature Journal 39, 75-134.

Nilsson S. 1962 - Some aquatic hyphomycetes from South America. Svensk Botanisk Tidskrift 56, 351-361.

Patil SY, Borse, BD. 2011 - Aquatic fungi from north Maharashtra-vii. Recent Research in Science and Technology 3(5), 8-11.

Ranzoni FV. 1953 - The aquatic hyphomycetes of California. Farlowia 4, 353-398.

Rayner RW. 1970 - A Mycological Colour Chart. Commonwealth Mycological Institute, Kew.

Regelsberger B, Messner K, Descals E. 1987 - Species diversity in aquatic hyphomycetes in four Austrian streams. Mycotaxon 30, 439-454.

Rossmann A. 2007 - Report of the planning workshop for all fungi DNA barcoding. Inoculum 58, $1-5$.

Ruibal C, Guiedan C, Salbmann E, Gorbushina AA, Crous PW, Groenewald JZ, Muggia L, Grube M, Isola D, Schoch CL, Staley JT, Lutzoni F, de Hoog GS. 2009 - Phylogeny of rockinhabiting fungi related to Dothideomycetes. Studies in Mycology 64, 123-133.

Saitou N. 1996 - Reconstruction of gene trees from sequence data. Methods in Enzymology 266, 427-449.

Saitou N, Nei M. 1987 - The neighbor-joining method: a new method for reconstructing phylogenetic trees. Molecular Biology and Evolution 4, 406-425.

Santos-Flores CJ, Betancourt-López C. 1997 - Aquatic and water-borne Hyphomycetes (Deuteromycotina) in streams of Puerto Rico (including records from other Neotropical locations). Caribbean Journal of Science, Special Publication No. 2, 1-116.

Smits G, Fernández R, Cressa C. 2007 - Preliminary study of aquatic hyphomycetes from Venezuelan streams. Acta Botánica Venezuelica 30, 345-355.

Swofford DL, Olsen GJ, Waddell PJ, Hillis DM. 1996 - Phylogenetic Inference. In: McLaughlin DJ, McLaughlin EG, Lemke PA (eds) Molecular Systematics, pp 407-514, Sinauer Associates, Sunderland, Massachusetts.

Tamura K, Dudley J, Nei M, Kumar S. 2007 - MEGA4: Molecular Evolutionary Genetics Analysis (MEGA) software version 4.0. Molecular Biology and Evolution 24, 1596-1599.

Thompson JD, Higgins DG, Gibson TJ. 1994 - CLUSTAL W: improving the sensitivity of progressive multiple sequence alignment through sequence weighting, position-specific gap penalties and weight matrix choice. Nucleic Acids Research 22, 4673-4680.

Tubaki K. 1965 - Short note on aquatic spora in East New Guinea. Transactions of the Mycological Society of Japan 6, 11-14.

Tubaki K, Watanabe K, Manoch L. 1983 - Aquatic hyphomycetes from Thailand. Transactions of the Mycological Society of Japan 24, 451-457.

Vilgalys R. 2000 - Conserved primer sequences for PCR amplification and sequencing fromnuclear ribosomal RNA. http://www.biology.duke.edu/fungi/mycolab/primers.html)Vilgalys Lab, Duke University, USA.

Vilgalys R, Hester M. 1990 - Rapid genetic identification and mapping of enzymatically amplified ribosomal DNA from several Cryptococcus species. Journal of Bacteriology 172, 4238 4246. 
Webster J, Marvanová L, Eicker A. 1994 - Spores from foam from South African rivers. Nova Hedwigia 57, 379-398.

White TJ, Bruns T, Lee S, Taylor JW. 1990 - Amplification and direct sequencing of fungal ribosomal RNA genes for phylogenetics. In: Innis MA, Gelfand DH, Sninsky JJ, White TJ (eds) PCR protocols: a guide to methods and applications, pp 315-322, Academic Press, Inc. New York. 